\title{
TINERII ŞI LIBERTATEA CREDINŢEI ÎN EDUCAŢIA CREŞTINĂ
}

Adrian Ivan*

Abstract: The Young Man and the Liberty of Faith in the Christian Education. The process of education cannot be anything but an initiative based on the principle of personal liberty of the educated person. In this context, we believe that the educational ideal can be understood in the perspective of the discovering and promotion of the real liberty of human people. Therefore, the religious education not only that can theoretically confirm the principle of human liberty, but can also organize the entire process of human development through a free and perfect affirmation of human person.

The recent paradigms in the process of education are centered on the diversity of opinion of the one that receives it and also the one that offers the educational formation. Moreover, the educational items can also imply a large diversity. However, even under these conditions, the religious education confirms that the educational pattern is of the utmost importance in any formative approach through the free will of the one that is educated. Obviously, the actual debates about the religious class brought into question many important aspects concerning the theory of education. Our study is dedicated to some theological analyses regarding the personal liberty in relation to the effort the educational pattern of Christian becoming as a purpose of education.

Keywords: Religious Education, Cristian Education, liberty, faith, conscience, school, Church.

\section{Introducere}

Posibilitatea realizării educaţiei este ea însăşi expresia cea mai elocventă a libertăţii omului. În teoria educaţiei, întâlnim permanent precizarea că procesul educativ se centrează pe persoana celui educat şi că diversitatea opţiunilor lui impune respectarea principiului autonomiei sau libertăţii individuale. $\mathrm{Cu}$ toate acestea,

* PhD, Associate Professor, University of Craiova, Faculty of Orthodox Theology, Craiova, Romania. 
educaţia, şi aici ne rezumăm doar la educaţia şcolară, deşi conceptul de educaţie tinde să transgreseze graniţele tuturor preocupărilor individului până la vârsta maturizării şi mai târziu, nu asigură dimensiunea însăşi a acestei libertăţi, ci doar o afirmă, o evidenţiază sau o pune în lumină. $\mathrm{Cu}$ alte cuvinte, educaţia are ca premisă libertatea persoanei celui educat, dar rămâne marea întrebare: în ce măsură finalitatea educaţiei se identifică în cele din urmă cu libertatea însăşi. În fapt, se observă că profesionalizarea procesului de educaţie înseamnă pe de o parte că substratul moral-civic pe care îl presupune educaţia se transferă în cea mai mare parte subiectului educat, şi aceasta pune în evidenţă mai ales libertatea individuală, în timp ce exerciţiul educaţiei nu face decât să îl responsabilizeze pe elev în faţa propriei libertăţi. Rămâne de văzut dacă o astfel de responsabilitate depăşeşte posibilităţile celui educat.

Dezbaterea privind dreptul individual de a alege liber posibilitatea educaţiei religioase, nu numai a răspuns la unele întrebări, dar a generat noi posibilităţi de abordare a drepturilor privind libertatea individuală. Spre exemplu: Când şi în ce condiţii dobândeşte un elev conştiinţa propriei religiozităţi? Cine este responsabil de formarea lui până la libera exprimare a voinţei religioase? Care este rolul părinţilor şi al familiei în exercitarea dreptului la libertate?

Religia în şcoală pare a deveni un adevărat exerciţiu al libertăţii persoanei în virtutea faptului că, în mod evident, a fi religios se identifică cu idealul libertăţii persoanei umane. Cel care se declarăreligios pare a avea responsabilitatea acestei religiozităţi mai ales în condiţiile unei presiuni a areligiozităţii sau a indiferentismului religios, nu numai a unei conştiinţe religioase proprii. De aici, înţelegem că raportarea tinerilor la educaţia religioasă ca expresie a libertăţii lor este o temă de maximă importanţă pentru pedagogia românească, în condiţiile vehiculării distorsionate a valorilor credinţei. Totuşi, nu trebuie dedus că problema libertăţii este una generată exclusiv de starea lucrurilor actuale, ci mai degrabă de substanța sau fundamentul învățăturilor creştine. 


\section{Libertatea omului ca expresie a libertăţii Creatorului}

Omul este o fiinţă raţională, liberă, nu în virtutea libertăţii individuale, ci a libertăţii cu care Creatorul său 1-a înzestrat.Sfântul Vasile cel Mare, spre exemplu, arată că omul, pe temeiul voinţei sale libere, este superior tuturor celor zidite de Dumnezeu şi că expresia libertăţii lui este manifestare a chipului dumnezeiesc din el. ${ }^{1}$

Sf. Grigorie de Nyssa, de asemenea, subliniază că omul, în perspectiva devenirii lui, se raportează permanent la modelul după care a fost zidit. Absenţa unei însuşiri a omului în raport cu acest model înseamnă şi o îndepărtare de asemănarea cu el. Firesc, libertatea omului se manifestă nu atunci când ea se defineşte prin prisma imperativelor eului sau limitelor lui de cunoaştere, ca descoperire a adevărului în graniţele sinelui ${ }^{2}$, la modalităţi concrete de realizare a voinţei subiectului, ci prin asemănarea liber consimţită cu modelul. „Chipul e chip numai câtă vreme nu-i lipseşte nicio însuşire din câte se pot atribui originalului, iar din clipa în care dimpotrivă se îndepărtează de original, din acel moment el nu mai este chip. Dacă, aşadar, una din caracterisiticile privitoare la Fiinţa dumnezeiască este aceea de a nu putea fi înţeleasă cu mintea, atunci neapărat că şi în această privinţă chipul trebuie să fie asemănător modelului."

Evident, Sf. Grigorie de Nyssa are în vedere şi calitatea omului de a fi fiinţă raţională, liberă, în contextul în care descrie

\footnotetext{
${ }^{1}$ Sf. Vasile cel Mare, Omilii la Psalmi, XLVIII, PG 29, col. 449C, apud Marius Telea, Antropologia Sfinţilor Părinţi Capadocieni, ediţia a II-a, Editura Emia, p. 245.

${ }^{2}$ Dictonul cartesian «Mă îndoiesc, deci cuget; cuget, deci exist» identifică şi limitează adevărul cunoaşterii la limitele posibilităţii subiectului de a-1 cunoaşte. Dacă pe Dumnezeu nu Îl pot cunoaşte ca pe mine însumi, nu înseamnă că El nu există, ci că El există, dar se deosebeşte fiinţial de mine. Vezi şi analiza lui Nikolaos Loudovikos,

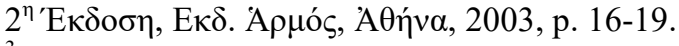

${ }^{3}$ Sf. Grigorie de Nyssa, Despre facerea omului, trad. de Pr. prof. dr. Teodor Bodogae, Bucureşti, Editura Institutului Biblic şi de Misiune al Bisericii Ortodoxe Române, 1998, p. 33-34.
} 
posibilitatea asemănării cu Dumnezeu, dar această libertate o fundamentează pe apropierea de Original a chipului.

Datul ontologic, din punct de vedere pedagogic, este sinonim cu calitatea fiinţării bune a omului, aşadar, a fi liber din perspectiva actului originării sale, înseamnă pentru om să parcurgă prin cunoaştere şi desăvârşire drumul către Raţiunea însăşi. De aceea, oamenii primesc porunca în mod direct: "Creşteţi şi vă înmulţiţi şi umpleţi pământul şi-l supuneţi; şi stăpâniri peste peştii mării, peste păsările cerului, peste toate animalele, peste toate vietăţile ce se mişcă pe pământ şi peste tot pământul!" ${ }^{4}$ Cum spuneam, porunca lui Dumnezeu arată dimensiunea libertăţii omului, care trimite la demnitatea lui raţională de a stăpâni, de a subscrie raţiunilor tuturor celor zidite.

În raport cu sine, însă, Dumnezeu i-a rânduit nu numai perspectiva asemănării cu El, dar i-a oferit şi modalitatea devenirii, instrumentul sau exerciţiul libertăţii şi acesta era porunca de a nu mânca din roadele pomului cunoştinţei binelui şi răului.

Deplina liberate pe care Dumnezeu a rânduit-o omului în rai însumează însă şi exerciţiul libertăţii lui în raport cu răul, nu însă în egală măsură cu săvârşirea celor proprii firii. De aceea, la momentul poruncii să nu mănânce din pomul cunoştinei binelui şi răului, Dumnezeu nu explică raţional necesitatea împotrivirii de a săvârşi răul, pe motivul că acesta nu are în Dumnezeu o raţiune, aşadar nu există în sensul existenţei oamenilor, ci este de fapt un accident. Aşadar, esenţa sau fundamentul libertăţii cu care Dumnezeu Însuşi 1a înzestrat pe om stă în descoperirea raţiunii existenţei noastre în El.

Faţă de posibilitatea de a greşi, se ridică întebarea dacă nu cumva tocmai săvârşirea răului certifică existenţa reală a libertăţii. Sfântul Maxim Mărturisitorul descrie răul astfel: „Răul nici nu era, nici nu va fi ceva ce subzistă prin firea proprie. Căci nu are în nici un fel fiinţă, sau fire, sau ipostas, sau putere, sau lucrare în cele ce sunt. $\mathrm{Nu}$ e nici calitate, nici cantitate, nici relaţie, nici loc, nici timp, nici

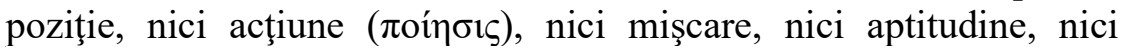
patimă (pasivitate, afect) contemplată în chip natural în vreo

\footnotetext{
${ }^{4}$ Facere 1, 28.
} 
existenţă şi în nici una din acestea toate nu subzistă prin vreo înrudire naturală. Nu e nici început (principiu), nici mijloc, nici sfârşit. Ci ca să-1 cuprind într-o definiţie, voi spune că răul este abaterea

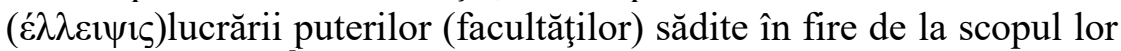
şi altceva nimic."

Dacă exerciţiul libertăţii se defineşte nu atât prin posibilitatea de a face răul, cât prin descoperirea celor deja existente în om, înseamnă că libertatea este condiţia primordială a existenţei raţionale şi a înţelegerii actului originării noastre. Iată de ce, în predarea Religiei în şcoală, este necesar ca teza creării omului de către Dumnezeu să nu fie eludată, ci să constituie punct de plecare în înţelegerea libertăţii credinţei.

A susţine libertatea nu înseamnă a introduce principiul autonomiei omului în raport cu Dumnezeu, pentru că aceasta coincide cu perspectiva autonomizării în raport cu Cel ce este şi din Care este. Autonomizarea omului în raport cu Dumnezeu este de fapt cauza morţii. Dumnezeu a zis: „În ziua în care vei mânca, vei muri negreşit” (Facere 2, 17). Diavolul i-a spus Evei: „Nu, nu veţi muri! Dar Dumnezeu ştie că în ziua în care veţi mânca din el vi se vor deschide ochii şi veţi fi ca Dumnezeu, cunoscând binele şi răul" (Facere 3, 4-5).

În schimb, în cazul celui ce devine credincios lui Dumnezeu, libertatea sinelui e resimţită ca deplină încredinţare faţă de Dumnezeu. Iată de ce Sf. Apostol Pavel stăruia zicând: „M-am răstignit împreună cu Hristos; şi nu eu mai trăiesc, ci Hristos trăieşte în mine. Şi viaţa de acum, în trup, o trăiesc în credinţa în Fiul lui Dumnezeu, Care m-a iubit şi $\mathrm{S}-\mathrm{a}$ dat pe Sine însuşi pentru mine" (Galateni 2, 20). De altfel, Sf. Maxim Mărturisitorul subliniază că ,primul om, neducându-şi mişcarea lucrării puterilor naturale spre scop, s-a îmbolnăvit de necunoştinţa cauzei sale..., şi-a amestecat cu încăpăţânare în toată simţirea toată puterea cugetătoare şi aşa a

5 Sf. Maxim Mărturisitorul, Răspunsuri către Talasie, trad. de pr. prof. D. Stăniloae, Filocalia, vol. 3, Bucureşti, Editura Institutului Biblic şi de Misiune al Bisericii Ortodoxe Române, 2009, p. 32-33. 
îmbrăţişat cunoştinţa compusă şi pierzătoare, producătoare de patimă, a celor sensibile."

$\mathrm{Cu}$ alte cuvinte, libertatea nu este însăşi fiinţa noastră, ci expresia fiinţării noastre bune, ea determină existenţa, modul de a fi, sensul, telosul. Când vorbim despre scopul libertăţii, din această perspectivă, înţelegem telosul ca afirmare a originii omului şi nu ca înstrăinare de ea.

Aşadar, libertatea este mai mult decât un drept individual, cetăţenesc, ea este prima condiţie a existenţei raţionale a omului şi, firesc, acest desiderat este unul în esenţă pedagogic, adică vizează finalitatea existenţei. „Alegerea este determinantă pentru calitatea spirituală a omului." "’ Întregul edificiu al educaţiei fiind unul spiritual, libertatea se manifestă în orice acţiune umană, cu atât mai mult în vehicularea cunoştinţelor religioase.

Chiar şi după căderea în păcat, libertatea omului, înţeleasă ca posibilitate a lui de a săvârşi binele, nu este întreruptă, dar nici nu este trecută cu vederea consecinţa directă a neascultării şi anume moartea. ${ }^{8}$ Moartea a devenit exponentul sfârşitului vieţii, implicit al libertăţii omului, nu al libertăţii de a înainta în Dumnezeu, ci ea se impune ca sfârşit al răutăţii, pentru ca experienţa negativă a libertăţii să nu fie fără de sfârşit. „Şi a zis Domnul Dumnezeu: „Iată Adam s-a făcut ca unul dintre Noi, cunoscând binele şi răul. Şi acum nu cumva să-şi întindă mâna şi să ia roade din pomul vieţii, să mănânce şi să trăiască în veci!...De aceea 1-a scos Domnul Dumnezeu din grădina cea din Eden, ca să lucreze pământul, din care fusese luat" (Facere 3, 22-23).

Astfel, în Vechiul Testament, libertatea este subliniată antitetic, ca alegere între viaţă şi moarte, şi mai puţin ca posibilitate şi continuitate ontologică. Alegerea binelui şi stăruinţa în săvârşirea lui apar ca fiind în raport de egalitate cu cel al alegerii răului. Până

\footnotetext{
${ }_{7}^{6}$ Sf. Maxim Mărturisitorul, op. cit., p. 33.

${ }^{7}$ Constantinia Iorda, Educaţia preşcolarilor după principiile Sfântului Ioan Gură de Aur, Bucureşti, Editura Sophia, 2009, p. 29

${ }^{8}$ Vezi şi Hierotheos, Mitropolit de Nafpaktos, Persoana în Tradiţia Ortodoxă, Bacău, Editura Bunavestire, 2002, p. 280-281.
} 
astăzi, cel care nu crede în Dumnezeu spune că este un drept al său, devreme ce este posibil să se opună Lui. În aceste condiţii, cu cât omul îşi face mai aproape posibilitatea de a se împotrivi lui Dumnezeu, cu atât libertatea îi apare mai eficientă, iar prezenţa lui Dumnezeu nefastă.

Observăm că textele veterotestamentare argumentează libertatea mai ales din perspectiva omului care caută izbăvirea din cercul vicios al păcatului şi al morţii: „Iată, eu vă pun astăzi înainte binecuvântare şi blestem: Binecuvântare veţi avea dacă veţi asculta poruncile Domnului Dumnezeului vostru, pe care vi le spun eu astăzi; iar blestem, dacă nu veţi asculta poruncile Domnului Dumnezeului vostru,ci vă veţi abate de la calea pe care v-o poruncesc astăzi şi veţi merge după dumnezei pe care nu-i ştiţi" (Deuteronom 11, 26-28) sau în alt loc: „Martori înaintea voastră iau astăzi cerul şi pământul: viaţă şi moarte v-am pus eu astăzi înainte, şi binecuvântare şi blestem. Alege viaţa ca să trăieşti tu şi urmaşii tăi” (Deuteronom 30, 19).

\section{Pedagogia Fiului lui Dumnezeu întrupat ca eliberare din robia păcatului şi a morţii}

Experienţa negativă a omului în ceea ce priveşte libertatea, până la venirea Mântuitorului Hristos, este subliniată deseori prin cuvintele Mântuitorului, în raport cu înţelesul libertăţii pe care îl atribuiau iudeii. Unul dintre aceste dialoguri redau substanţial faptul că sensul adevărat al libertăţii omului nu se deduce prin raportarea imediată la desideratele omului, ci prin referirea la Adevărul Însuşi. „Deci zicea Iisus către iudeii care crezuseră în El: Dacă veţi rămâne în cuvântul Meu, sunteţi cu adevărat ucenici ai Mei;Şi veţi cunoaşte adevărul, iar adevărul vă va face liberi.Ei însă I-au răspuns: Noi suntem sămânţa lui Avraam şi nimănui niciodată n-am fost robi. Cum zici Tu că: Veţi fi liberi? Iisus le-a răspuns: Adevărat, adevărat vă spun: Oricine săvârşeşte păcatul este rob al păcatului.Iar robul nu rămâne în casă în veac; Fiul însă rămâne în veac. Deci, dacă Fiul vă va face liberi, liberi veţi fi într-adevăr" (Ioan 8, 33-36). 
În contextul istoriei poporului iudeu, libertatea apare ca relaţie socială, cu neputinţă de a constitui premisă a înţelegerii adevăratei libertăţi. Astfel, Mântuitorul atrage atenţia că aşa-zisa libertate a celui păcătos nu poate de fi de durată: ,,robul nu rămâne în casă în veac; Fiul însă rămâne în veac." Este numită aici în mod evident robie aşa-zisa libertate negativă, iar libertatea în sensul credinţei este numită filiaţie, înrudire cu Dumnezeu. Robul sau fiul, amândoi sunt chemaţi să împlinească aceleași fapte: unul se arată potrivnic socotindu-se liber, celălalt se face rob cunoscându-şi calitatea de fiu. ${ }^{9}$

De remarcat că Mântuitorul Hristos subliniază adesea că învăţătura Sa despre libertatea credinţei nu este una teoretică, abstractă, ci îmbracă complexitatea relaţiei dintre Tatăl şi Fiul. În interiorul acestei relaţii se întemeiază sensul creştin al libertăţii. Este o libertate în iubire. Astfel, Mântuitorul, în descrierea libertăţii, scoate în evidenţă nu numai calitatea Sa de Fiu al Tatălui, ci şi de Cel care trimite de la Tatăl pe Duhul Sfânt, în sensul că El, prin Jertfa Sa, retrimite în lume pe Duhul Sfânt, Duhul Adevărului, care de la Tatăl purcede şi despre Care spune: „vă va călăuzi la tot adevărul” (Ioan 16, 13) şi Acela, Adevărul, „,vă va face liberi” ( Ioan 8, 32).

Iisus Hristos este Mântuitorul, adică Cel care redă omului sensul primordial al libertăţii. Pentru aceasta, El este „Calea, Adevărul şi Viaţa” (Ioan 14, 6). El Însuşi a arătat dimensiunea libertăţii fiindcă în persoana Lui se întâlnesc deopotrivă atât libertatea cât şi alteritatea ${ }^{10}$. Libertatea, pentru că este Dumnezeu, iar în persoana Lui, firea umană a urmat întru totul firii dumnezeieşti, sa desăvârşit ca libertate a Fiului lui Dumnezeu. Prin aceasta, putem spune că Dumnezeu a cugetat libertatea omului şi din perspectiva lui,

9 Împlinirea voinţei Tatălui îl defineşte pe Fiul, care se împărtăşeşte prin aceasta nu numai de libertatea Tatălui, ci şi de iubirea Lui. Cine Îl numeşte pe Dumnezeu Tată fără să împlinească voia Lui, acela Îl face pe Dumnezeu Părinte al răutăţii lui. Vezi la Sf. Grigorie de Nyssa, Despre Rugăciunea domnească , PSB vol. 29, trad. de pr. prof. D. Stăniloae, Bucureşti, Editura Institutului Biblic şi de Misiune al Bisericii Ortodoxe Române, 1982, p. 417.

10 Vezi Ioannis Zizioulas, Comuniune şi alteritate. Fiinţarea personaleclesială, trad. de Pr. dr. Liviu Barbu, Editura Sophia, Bucureşti, 2006, p. 65. 
cunoscând El însuşi şi asumând lupta lui împotriva robiei păcatului şi a morţii. Învierea Domnului şi Înălţarea la cer a Domnului arată desăvârşirea acestei libertăţi.

Clement Alexandrinul încearcă să surprindă această continuitate între libertatea lui Dumnezeu şi libertatea omului astfel: „După cum este lăudat cel care se foloseşte de puterea sa, ca să trăiască virtuos, tot aşa este cu mult mai sfânt şi mai vrednic de adorat Dumnezeu Cel care ne-a dat libertate şi stăpânire, Cel care nea îngăduit să trăim cum voim şi n-a îngăduit să ajungem robi şi nici n-a voit ca alegerile şi feririle noastre să le facem din constrângere" 11 .

Mântuitorul pune în valoare această libertate a credinţei în El prin jertfa şi iubirea Lui faţă de oameni. Această iubire îi responsabilizează, însă, pe oameni nu numai în raport cu Dumnezeu, ci şi în raport cu semenii lor. De cele mai multe ori, libertatea credinţei este evidenţiată în public, prin participarea în comuniune la actul credinţei, şi implicit al vindecărilor pe care Mântuitorul le săvârşeşte. Adesea, Mântuitorul face referire la credinţa celorlalţi când vindecă pe slăbănog, pe fiica lui Iair sau pe fiul văduvei din Nain. Prin urmare, libertatea credinţei asumă şi o responsabilitate comunitară, nu numai individuală, aşa cum vedem în abordările sociologice actuale.

\section{3. Şcoala şi Biserica, în perimetrul coabitării sociale}

În general, cele două instituţii sunt văzute ca având cel mai important rol în formarea tinerilorprintr-o permanentă conlucrare la nivel social. Cele două instituţii urmăresc standarde şi modalităţi de realizare a binelui comun. Şcoala şi Biserica sunt două instituţii care se bazează pe încrederea şi consimţirea tuturor în faţa valorilor comune. Libertatea pe care Biserica o recunoaşte credincioşilor ei îşi are reperele în demnitarea şi superioritatea omului în creaţie, aşa cum am văzut, încă de la zidirea lui.

${ }^{11}$ Clement Alexandrinul, Stromatele, III, 5, PSB vol. 5, trad. de Pr. prof. D. Fecioru, EIBMBOR, Bucureşti, 1982, p. 204. 
În România, Biserica şi Şcoala au un trecut comun, un «symbiosis» cultural, civic. Mai mult, societatea românească se defineşte în perimetrul religios al tradiţiilor, culturii religioase sau artei creştine. De asemenea, familia creştină se bazează pe principii religioase, iar primele forme ale educaţiei în familie sunt strâns edificate pe respectul şi trăirea funciară a sacrului. ${ }^{12}$ Adeziunea liberă la valorile credinţei se produce în contextul bucuriei descoperirii sacrului, a resemnificării cotidianului cu implicaţii formative, nu prin prisma adoptării unei poziţii de forţă în raport cu posibilitatea refuzului credinţei religioase. Convingerile religioase au un alt substrat deliberativ, cel al conştiinţei, iar nivelul persuasiv al acestora îl asigură nu atât calculele sociale, cât descoperirea şi perceperea unei ordini morale. De aceea, educaţia religioasă încearcă să surprindă armonia şi continuitatea valorică între mediile sociale, între subiectivitate şi obiectivitate.

Raportul constructiv între raţionalitatea omului şi raţionalitatea creaţiei este evidenţiat şi mai mult în pedagogie ca afirmare a libertăţii persoanei umane. Spre exemplu, renumitul cercetător Jean Piaget subliniază că, în dezvoltarea inteligenţei la copii prin actul cunoaşterii, aceştia tind să dezvolte o gândire corelativă atât inteligenţei sau raţiunii proprii firii umane, cât şi raţionalităţii sau „regularităţii” pe care o presupune lumea sau exteriorul ei. ${ }^{13} \mathrm{La}$ religie se are în vedere mai ales acest desiderat al continuităţii axiologice dintre persoană şi mediul de educaţie şi formare, în special mediul social.

Cât timp Biserica şi Şcoala păstrează un raport firesc în identificarea şi promovarea valorilor sociale, procesul de educaţie presupune în mod firesc, eficient, dimensiunea receptării sacrului în formarea şi dezvoltarea umană. Desigur, percepţia sacrului este astăzi mult diminuată şi viciată în condiţiile vehiculării unor teorii seculariste, de sorginte anticreştină, antibisericească. În afara acestei

\footnotetext{
${ }^{12}$ Vezi sărbătorirea numelui, cultul morţilor, obiceiurile creştine din perioada marilor sărbători, tot mai prezente şi în arealul urban, etc.

13 Jean Piaget, Construirea realului la copil, Bucureşti, Editura Didactică şi Pedagogică, 1976, p. 317.
} 


\section{$15^{\text {th }}$ International Simposium on Science, Theology and Arts}

propagande antibisericeşti, rămâne preocuparea evidentă în identificarea mijloacelor şi metodelor de transmitere autentică a conţinutului credinţei, implicit a formelor tradiţionale de exprimare şi transmitere a trăirii religioase.

Plecând de la acest aspect, putem observa că problema respectării libertăţii individuale în cazul orei de religie nu este una întâmplătoare. Ea este propusă de cei care susţin că ora de religie trebuie să fie o oră de educaţie morală şi atât. Explicaţia este subversivă, în sensul că educaţia morală poate fi orice, dar nu religioasă, sau poate fi plurireligioasă în scopul relativizării religioase, confesionale.

De remarcat că, în conceptul pedagogiei constructiviste, se vorbeşte deja despre o morală postcreştină şi ea este dedusă strict pe baza evaluării sau implementării regulilor sociale, denumită chiar „morala acceptării şi respectului reciproc”. În esenţă, această morală are ca scop stabilirea unor reguli de comportament pe baza cărorase urmăreşte buna convieţuire. Mult mai interesant este de observat că această morală creează premisele relativizării oricăror principii religioase în viaţa morală. Conform acestor teorii, „morala nu mai este un dat incontestabil şi de la sine înţeles, ca în comunitatea creştină. Acum, a o justifica înseamnă să poţi arăta de ce ar trebui toţi oamenii, fără excepţie, să se raporteze la ea, să o considere corectă şi raţională şi să o urmeze precum poruncile lui Dumnezeu. Ea îşi poate realiza justificarea doar dacă este inteligibilă pentru fiecare, astfel încât să se poată cere ascultare/supunere."14

Altfel spus, educaţia religioasă, în contextul teoriilor bazate pe exigenţa respectării libertăţii individuale se apropie foarte mult de o morală socială de tip constructivist. În esenţă, aceste teorii vizează nu atât integritatea libertăţii individuale, cât relativizarea normelor religios-morale autentice. De aceea, susţinătorii acestor teorii afirmă că au abandonat definitiv premisele unei societăţi care acceptă in integro o morală aşa cum este morala creştină. Referindu-se la perioada medievală, ei susţin:

${ }^{14}$ Horst Siebert, Pedagogie constructivistă, Editura Institutul European, 2001, p. 69. 
„În comunitatea creştină medievală, indivizii, care încă nu erau indivizi în sensul actual al cuvântului, formau o unitate indestructibilă cu comunitatea în care trăiau. Acestei situaţii îi corespundea o teorie a cunoaşterii care se baza pe faptul că toţi pot cunoaşte aceeaşi realitate în acelaşi mod. Cea mai cunoscută expresie a acestei teorii o regăsim în formula lui Toma d'Aquino adaequatio rei et intellectus, formulă care suş̧inea că se consideră a fi adevărat doar ceea ce dovedeşte armonia dintre lucrurile cunoscute şi ceea ce urmează a fi cunoscut. Individul era deci obligat să facă apel la ceva «obiectiv», concept căruia constructiviştii îi întorc cu groază spatele."15

$\mathrm{Nu}$ vom încerca să argumentăm pro sau contra acestor teorii, însă, libertatea credinţei în arealul formativ al şcolii româneşti răspunde unei realităţi obiective, aceea că, în majoritatea lor, elevii sunt membri ai Bisericii. Aşadar, ei au calitatea de credincioși înainte de a deveni elevi sau beneficiari ai procesului de educaţie şi formare în şcoală. Libertatea de credinţă a tinerilor este o temă care vizează societatea în general, nu numai şcoala. Evident că Religia este o disciplină şcolară şi ea respectă libertatea elevului în spaţiul obiectiv al şcolii, ceea ce au demonstrat studiile şi cercetările realizate pană la acest moment $^{16}$, dar a-i interoga pe elevii care sunt deja membrii ai Bisericii dacă consimt cu educaţia religioasă este un nonsens şi contraproductiv. Se produce mai degrabă nu un exerciţiu al libertăţii, cât o relativizare a disciplinei Religie în primul rând şi,în plan secundar, a principiilor de educaţie, a regulilor şcolare.F.-W. Fœrster susţinea că ,şcoala nu-şi poate întocmi programele după gusturile

\footnotetext{
${ }_{16}^{15}$ Ibidem, p. 66.

16 Vezi Dorin Opriş, Monica Opriş (coord.), Religia şi şcoala. Cercetări pedagogice, studii şi analize, Bucureşti, Editura Didactică şi Pedagogică, R.A., 2011; Monica Ciucureanu, Simona Velea, Educaţia moral-religioasă $\hat{\imath}$ sistemul de educaţie din România, Bucureşti, Editura Didactică şi Pedagogică, R.A., 2012; Patriarhia Română, Apostolat educaţional, Ora de religie cunoaştere şi devenire spirituală, Bucureşti, Editura Basilica, 2010.
} 
tinerilor şcolari... Un cult peste măsură al individului, al drepturilor şi nevoilor lui e nesănătos." ${ }^{\prime 17}$

Şcoala este astfel un spaţiu de învăţare prin experienţă, prin tatonare, prin interacţiune şi comuniune, dar nu este nicidecum un spaţiu de interacţiune a teoriilor sau filosofiilor antireligioase, cu atât mai mult cu cât experienţa anilor de comunism au scos în evidenţă că educaţia religioasă s-a păstrat şi se păstrează în familie şi astfel impune măsuri de asigurare a continuităţii valorice în şcoală.

\section{Concluzii}

Tinerii sunt prin excelenţă cea mai mare investiţie a unei societăţi, a unei naţiuni. Importanţa educaţiei şi formării lor profesionale nu exclude, ci implică şi necesită educaţia religioasă. Firesc, libertatea este un principiu fundamental al existenţei omului şi respectarea lui înseamnă cunoaşterea şi respectarea realităţii lui ontologice. Educaţia religioasă nu trebuie definită strict prin prisma normelor morale, ci pe baza respectării principiului libertăţii şi al desăvârşirii omului în raport cu Dumnezeu şi cu semenii.

Experienţa ultimilor ani a adus în primplanul social dezbaterea privind dreptul individual al elevilor de a alege ora de religie. Libertatea conştiinţei elevilor este profund afectată chiar în condiţiile invocării unor alternative etice. Educaţia religioasă nu are alternative, fiind ea însăşi fundamentată pe principiul desăvârşirii omului prin deplina afirmare a libertăţii lui în Dumnezeu. Prin urmare, tema libertăţii credinţei în educaţia tinerilor nu reprezintă un concept închis, ci trebuie abordat şi explicat în manieră didactică, teologică, argumentat prin experienţa şi viaţa Bisericii şi, în primul rând, prin experienţa elevilor.

\footnotetext{
${ }^{17}$ F.-W. Fœrster, Şcoala şi caracterul, trad. de Stelian I. Constantinescu, ediţia a III-a, Cugetarea, Georgescu Delafras, p. 106-108.
} 


\section{Bibliografie}

1. Alexandrinul, Clement, Stromatele, III, 5, PSB vol. 5, trad. de Pr. prof. D. Fecioru, EIBMBOR, Bucureşti, 1982.

2. Sf. Grigorie de Nyssa, Despre facerea omului, trad. de Pr. prof. dr. Teodor Bodogae, Bucureşti, Editura Institutului Biblic şi de Misiune al Bisericii Ortodoxe Române, 1998.

3. Idem, Despre Rugăciunea domnească, PSB vol. 29, trad. de pr. prof. D. Stăniloae, Bucureşti, Editura Institutului Biblic şi de Misiune al Bisericii Ortodoxe Române, 1982.

4. Sf. Maxim Mărturisitorul, Răspunsuri către Talasie, trad. de pr. prof. D. Stăniloae, Filocalia, vol. 3, Bucureşti, Editura Institutului Biblic şi de Misiune al Bisericii Ortodoxe Române, 2009.

5. Sf. Vasile cel Mare, Omilii la Psalmi, XLVIII, PG 29.

6. Ciucureanu, Monica; Velea, Simona, Educaţia moral-religioasă în sitemul de educaţie din România, Bucureşti, Editura Didactică şi Pedagogică, R.A., 2012.

7. Iorda, Constantinia, Educaţia preşcolarilor după principiile Sfântului Ioan Gură de Aur, Bucureşti, Editura Sophia, 2009.

8. Hierotheos, Mitropolit de Nafpaktos, Persoana în Traditia Ortodoxă, Bacău, Editura Bunavestire, 2002.

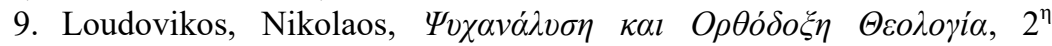

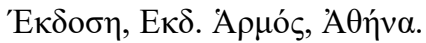

10. Patriarhia Română, Apostolat educaţional, Ora de religie - cunoaştere şi devenire spirituală, Bucureşti, Editura Basilica, 2010.

11. Opriş, Dorin; Opriş, Monica (coord.), Religia şi şcoala. Cercetări pedagogice, studii şi analize, Bucureşti, Editura Didactică şi Pedagogică, R.A., 2011.

12. Piaget, Jean, Construirea realului la copil, Bucureşti, Editura Didactică şi Pedagogică, 1976. 2001.

13. Siebert, Horst, Pedagogie constructivistă, Editura Institutul European,

14. Telea, Marius, Antropologia Sfinţilor Părinţi Capadocieni, ediţia a IIa, Editura Emia.

15. F.-W. Fœrster, Şcoala şi caracterul, trad. de Stelian I. Constantinescu, ediţia a III-a, Cugetarea. Georgescu Delafras.

16.Zizioulas, Ioannis, Comuniune şi alteritate. Fiinţarea personaleclesială, trad. de Pr. dr. Liviu Barbu, Bucureşti, Editura Sophia, 2006. 